\title{
Pembelajaran Menulis Kalimat Poster Menggunakan Metode Inkuiri di Madrasah Tsanawiyah
}

\section{Learning to Write Poster Sentences Using the Inquiry Method at Madrasah Tsanawiyah}

\section{Maya Bangun Palinda ${ }^{1}$}

Artikel diterima editor tanggal 09-03-2021, disetujui untuk dipublikasikan tanggal 29-05-2021 Doi: $x x x x x-x x x x x$

\begin{abstract}
Abstrak
Penelitian ini dilatarbelakangi oleh masih rendahnya kemampuan menulis pada siswa, khususnya dalam penulisan kalimat poster. Kenyataannya pada saat ini masih banyak siswa MTs Daarul Uluum PUI Majalengka yang belum mampu menulis kalimat poster secara benar.Tujuan dalam penelitian ini adalah sebagai berikut. 1) Mendapatkan data mengenai kemampuan siswa kelas VIII MTs Daarul Uluum PUI Majalengka dalam menulis kalimat poster sebelum pembelajaran dengan menggunakan metode inkuiri. 2) Mendapatkan data mengenai kemampuan siswa kelas VIII MTs Daarul Uluum PUI Majalengka dalam menulis kalimat poster setelah pembelajaran dengan menggunakan metode inkuiri. 3) Mendapatkan data mengenai efektivitas penggunaan metode inkuiri dalam pembelajaran menulis kalimat poster siswa kelas VIII MTs Daarul Uluum PUI Majalengka Metode yang digunakan dalam penelitian ini adalah metode deskriptif sedangkan teknik yang digunakan yaitu teknik pengumpulan data serta teknik pengolahan dan analisis data. Populasi penelitian adalah siswa kelas VIII MTs Daarul Uluum PUI Majalengka sebanyak 5 kelas dengan jumlah populasi 200 siswa. Sampel dalam penelitian ini adalah 1 kelas yaitu kelas VIII B dengan jumlah siswa 35 orang. Hasil dari pengolahan dan analisis data menunjukkan jawaban terhadap rumusan masalah yaitu hasil pretes kemampuan siswa dalam pembelajaran menulis kalimat poster masih rendah hanya mencapai 67,29\%, tetapi hasil postes terdapat peningkatan menjadi $84,57 \%$. Dengan tingkat efektivitas penggunaan metode inkuiri dalam pembelajaran menulis kalimat poster memiliki korelasi $0,464 \%$ termasuk kategori sedang.
\end{abstract}

Kata kunci: pembelajaran, menulis kalimat, poster, metode inquiry.

\begin{abstract}
This research is motivated by the low writing ability of students, especially in writing poster sentences. In fact, at present, there are still many students at MTs Daarul Uluum PUI Majalengka who have not been able to write poster sentences correctly. In addition to the formulation of the problem, this study also has a purpose. The objectives of this study are as follows. 1) Obtain data about the ability of class VIII students of MTs Daarul Uluum PUI Majalengka in writing poster sentences before learning using the inquiry method. 2) Obtain data about the ability of class VIII students of MTs Daarul Uluum PUI Majalengka in writing poster sentences after learning using the inquiry method. 3) Obtaining data
\end{abstract}

${ }^{1}$ Maya Bangun Palinda, MTsN 14 Majalengka, mayabangunpalinda800@gmail.com 
about the effectiveness of using the inquiry method in learning to write poster sentences for class VIII students of MTs Daarul Uluum PUI Majalengka. The method used in this research is a descriptive method, while the techniques used are data collection techniques and data processing and analysis techniques. The population of the study was 5-grade students of MTs Daarul Uluum PUI Majalengka with a total population of 200 students. The sample in this study was 1 class, namely class VIII B with 35 students. The results of data processing and analysis showed the answer to the problem formulation, namely the results of the pretest students' ability in learning to write poster sentences was still low, only reaching $67.29 \%$, but post-test results increased to $84.57 \%$. With the level of effectiveness of using the inquiry method in learning to write poster sentences, it has a correlation of $0.464 \%$, including the moderate category.

Keywords: learning, writing sentences, posters, inquiry method

\section{Pendahuluan}

Bahasa memiliki peranan penting bagi manusia yakni untuk berkomunikasi. Tanpa adanya komunikasi, manusia tidak dapat berinteraksi antara satu sama lain. Hal tersebut sesuai dengan pendapat Sugihastuti (2000) yang mengatakan bahwa, "Bahasa merupakan alat komunikasi yang efektif antar manusia". Seiring perkembangan zaman, bahasa telah menjadi suatu ilmu yang wajib dipelajari. Sehubungan dengan penggunaannya keterampilan berbahasa mempunyai empat komponen. Hal tersebut sesuai dengan pendapat Tarigan (2008) bahwa komponen dari keterampilan dalam berbahasa terdiri dari empat hal yaitu menyimak, berbicara, membaca dan menulis.

Tarigan (2008) mengatakan bahwa, "Menulis merupakan suatu keterampilan berbahasa yang dipergunakan untuk berkomunikasi secara tidak langsung, tidak secara tatap muka dengan orang lain". Menulis merupakan suatu keterampilan berbahasa yang menggunakan sarana tulisan untuk berkomunikasi dengan orang lain. Tulisan tersebut berisi gagasan yang ingin disampaikan penulis kepada pembaca. Hal tersebut sesuai dengan pendapat Tarigan (2008) yang menyatakan bahwa, "Setiap penulis mempunyai pikiran atau gagasan yang ingin disampaikan atau dituturkan kepada orang lain. Dalam hal ini ia harus menerjemahkan ide-idenya ke dalam sandi-sandi lisan yang selanjutnya diubah menjadi sandi-sandi tulis". Keterampilan menulis memerlukan latihan yang intensif karena bukan suatu keterampilan yang datang secara otomatis tetapi harus melalui latihan secara berkesinambungan.

Keterampilan menulis sangat penting dalam pelajaran bahasa Indonesia di Sekolah Menengah Pertama atau Madrasah Tsanawiyah, guru sebagai pengajar dituntut untuk mengajarkan keterampilan menulis secara profesional. Kualifikasi profesional tersebut tertuang dalam UndangUndang Guru dan Dosen Nomor 14 Tahun 2005 Pasal 8 yang menyebutkan "Guru wajib memiliki kualifikasi akademik, kompetensi, sertifikasi pendidik, sehat jasmani dan rohani, serta memiliki kemampuan untuk mewujudkan tujuan pendidikan nasional"(Hani Subakti, 2018). Atas dasar tersebut maka guru harus dapat menjadi direktur, fasilitator dan motivator adalah proses pembelajaran .

Guru sebagai fasilitator, menurut Koffka dalam Sanjaya (2011) melalui teori belajar Gestalt menjelaskan bahwa, "Perubahan perilaku itu disebabkan karena adanya insight dalam diri siswa, dengan demikian tugas guru adalah menyediakan lingkungan yang dapat memungkinkan setiap siswa bisa menangkap dan mengembangkan insight itu sendiri". Hal tersebut menjelaskan bahwa salah satu tugas guru adalah menyediakan lingkungan yang memungkinkan setiap siswanya dapat menangkap materi pembelajaran dan mengemukakan apa yang telah didapatnya sehingga siswa dapat menemukan sendiri jawaban atas permasalahannya. Siswa dapat menemukan sendiri jawaban atas permasalahannya akan mengakibatkan keterlibatan siswa secara maksimal dalam proses belajar sehingga munculnya motivasi siswa untuk belajar.

Guru sebagai salah satu sumber belajar berkewajiban menyediakan lingkungan belajar yang kreatif bagi kegiatan belajar siswa. Salah satu kegiatan yang harus guru lakukan adalah menentukan 


\section{JGI: JURNAL GURU INDONESIA}

2021, 1(1), hlm. 20 - 26

https://jurnal.ppjb-sip.org/index.php/igi/index

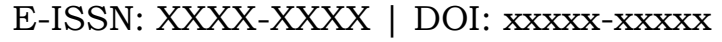

metode pembelajaran yang dipakai untuk mencapai tujuan pembelajaran. Hal tersebut sesuai dengan pendapat Djamarah dan Aswan Zain (2006) mengatakan bahwa, "Metode adalah suatu cara yang dipergunakan untuk mencapai tujuan yang telah ditetapkan". Menurut W.Gulo (2008) berpendapat bahwa, "There is no one best way to teach. The best technique is the one will be most effective for reaching a particular goal in a given situation". Hal tersebut menjelaskan bahwa tidak ada satu cara terbaik untuk mengajar. Teknik terbaik adalah suatu cara yang paling efektif untuk mencapai tujuan tertentu dalam situasi tertentu. Menurut Djamarah dan Aswan Zain (2006) mengatakan bahwa, "Berbagai sistem pengajaran yang menarik perhatian akhir-akhir ini adalah: enquiry-discovery approach, expository approach, mastery learning, dan humanistic education". Berkaitan dengan pembelajaran menulis kalimat poster, metode inkuiri dapat dijadikan sebagai metode dalam pembelajaran yang efektif. Kelebihan metode ini dalam pembelajaran menulis kalimat poster adalah siswa dapat menumbuhkan motivasi intrinsik untuk menulis kalimat poster berdasarkan pengetahuan dan kecakapannya, dapat memberikan ruang kepada siswa untuk belajar sesuai dengan gaya belajar mereka menulis kalimat poster, siswa akan mudah menghafal dan mengingat cara menulis kalimat poster yang baik.

Saat ini penggunaan bahasa Indonesia siswa di tingkat Madrasah Tsanawiyah (MTs) khususnya di MTs Daarul Uluum PUI Majalengka dalam menulis kalimat poster masih rendah. Berdasarkan tuntutan di atas, penulis merasa tertarik untuk mengadakan penelitian yang berkaitan dengan pembelajaran bahasa Indonesia di Madrasah Tsanawiyah (MTs) kelas VIII, khususnya dalam penggunaan metode pembelajaran inkuiri untuk meningkatkan kemampuan menulis kalimat poster siswa. Berdasarkan uraian di atas, maka seorang guru harus menguasai garapannya dalam proses pembelajaran dari mulai langkah perencanaan, pelaksanaan dan evaluasi disertai penggunaan suatu metode yang digunakan. Sejalan dengan hal tersebut penulis tertarik untuk mengadakan penelitian mengenai efektivitas penggunaan metode inkuiri dalam pembelajaran membuat kalimat poster siswa.

\section{Metode penelitian}

Metode yang penulis gunakan dalam penelitian ini adalah metode deskriptif karena metode deskriptif bertujuan untuk memecahkan masalah secara sistematis dan faktual mengenai fakta-fakta dan implikasi suatu masalah dalam pembelajaran membuat kalimat poster dengan menggunakan metode inkuiri siswa kelas VIII MTs Daarul Uluum PUI majalengka Tahun Ajar 2013/2014.

Sudjana \& Ibrahim (2001) mengemukakan langkah-langkah penelitian deskriptif sebagai berikut. Pertama, merumuskan masalah. Kedua penentuan jenis informasi yang dibutuhkan. Ketiga, ditentukannya prosedur atau langkah pengumpulan serta pengolahan data penelitian. Terakhir adalah menyimpulkan hasil penelitian yang telah dilakukan. Penulis menggunakan metode deskriptif melalui pendekatan studi analisis dan kepustakaan. Artinya dalam penelitian ini penulis memusatkan perhatian pada pemecahan-pemecahan masalah aktual yang ada pada masa sekarang. Hal tersebut sesuai dengan pendapat Surakhmad (2004) yang mengemukakan bahwa metode deskriptif memiliki ciri-ciri sebagai berikut. Pertama, masalah yang aktual. Kedua, interpretasi rasional yang seimbang terhadap masalah. Terakhir, mendeskripsikan hubungan, uji hipotesis dari suatu masalah.

Populasi dalam penelitian ini adalah siswa kelas VIII MTs Daarul Uluum PUI Majalengka Tahun Ajar 2013/2014 sebanyak 5 (lima) kelas dengan jumlah populasi 200 siswa. Penentuan sampel dalam penelitian ini yaitu menggunakan probability sampling. Probability sampling memiliki kelebihan, Sugiyono (2012) mengemukakan bahwa, "Probability sampling adalah teknik pengambilan sampel yang memberikan peluang yang sama bagi setiap unsur (anggota) populasi untuk dipilih menjadi anggota sampel". Dalam menentukan probability sampling, penulis menggunakan simpel random sampling. Sugiyono (2012) mengemukakan bahwa, "Dikatakan simple (sederhana) karena 
pengambilan anggota sampel dari populasi dilakukan secara acak tanpa memperhatikan strata yang ada dalam populasi itu".

Penentuan sampel melalui teknik simple random sampling tersebut berlaku untuk kelas VIII MTs Daarul Uluum PUI Majalengka. Adapun pengambilan sampel melalui teknik simple random sampling, penulis menggunakan cara undian. Penulis menulis nama tiap kelas di beberapa helai kertas, mulai dari kelas VIII A sampai dengan VIII E kemudian digulung dan dimasukan ke dalam tempat tertutup. Selanjutnya gulungan kertas tersebut dikocok lalu ke luarlah 1 (satu) gulungan kertas. Berdasarkan pengundian yang dilakukan penulis, keluar kertas bertuliskan kelas VIII B. Maka, sampel penelitian ini yaitu kelas VIII B dengan jumlah 35 siswa

Tujuan dari penelitian ini adalah mendapatkan data. penelitian ini memiliki sumber data yaitu nilai tes awal dan tes akhir hasil pembelajaran menulis kalimat poster dengan menggunakan metode inkuiri siswa kelas VIII MTs Daarul Uluum PUI Majalengka. Untuk memperoleh data tersebut dalam penelitian ini penulis menggunakan teknik pengumpulan data sebagai berikut.

Teknik Kepustakaan

Teknik kepustakaan ini dimaksudkan untuk memperoleh teori-teori dengan cara mempelajari materi untuk dipahami dan membaca buku-buku yang berhubungan dengan penelitian. Teori-teori tersebut penting untuk dijadikan landasan berfikir dan pemecahan masalah penelitian.

Teknik Tes. Teknik tes digunakan untuk mendapatkan data mengenai kemampuan menulis kalimat poster siswa kelas VIII MTs Daarul Uluum PUI Majalengka Tahun Ajar 2013/2014. Teknik ini dibagi ke dalam dua bagian yaitu sebagai berikut. Tes Awal (pretes),

Nurgiantoro (2010) berpendapat bahwa, "Pretes adalah jenis tes kemampuan awal yang dilakukan sebelum peserta didik mengalami proses belajar dalam suatu mata pelajaran". Berdasarkan pendapat tersebut maka pretes dalam penelitian ini adalah tes uraian terbuka tentang menulis kalimat poster, dengan tujuan mengetahui kemampuan awal siswa dalam menulis kalimat poster sebelum pembelajaran menulis kalimat poster menggunakan metode inkuiri. Kedua, tes Akhir (postes) yaitu tes setelah pembelajaran diaksanakan, hal ini selaras dengan penryataan Djamarah (2010) berpendapat bahwa, "Post-test yaitu tesl yang diberikan setelah proses pengajaran berakhir". Berdasarkan pendapat tersebut maka postes dalam penelitian ini merupakan tes uraian terbuka tentang menulis kalimat poster setelah proses belajar mengajar.

Data yang terkumpul dari nilai pretes dan postes, kemudian dianalisis secara kuantitatif dengan tujuan untuk mengetahui efektivitas penggunaan metode inkuiri dalam pembelajaran menulis kalimat poster siswa kelas VIII MTs Daarul Uluum PUI Majalengka Tahun Ajar 2013/2014. Teknik yang digunakan penulis untuk mengolah data tersebut adalah sebagai berikut.

\section{Teknik Prosentase (\%)}

Penentuan gambaran yang dimiliki siswa dalam pembelajaran menulis kalimat poster menggunakan teknik prosentase dari hasil pretes dan postes. Kriteria yang digunakan dalam teknik ini adalah sebagai berikut .

Tabel 1

Interpretasi Nilai Prosentase

\begin{tabular}{cc}
\hline Besarnya Nilai Prosentase & Interpretasi \\
\hline $0 \%$ & Tidak sedikitpun \\
$1 \%-24 \%$ & Hampir tidak ada \\
$25 \%-49 \%$ & Hampir separuhnya \\
$50 \%$ & Separuhnya \\
$51 \%-74 \%$ & Lebih dari separuhnya \\
$75 \%-99 \%$ & Hampir seluruhnya \\
$100 \%$ & Seluruhnya \\
\hline
\end{tabular}

(Somantri, 2006; (Rianto 2018)) 


\section{JGI: JURNAL GURU INDONESIA}

2021, 1(1), hlm. 20 - 26

https://jurnal.ppjb-sip.org/index.php/igi/index

E-ISSN: XXXX-XXXX | DOI: xxxxx-xxxxx

\section{Korelasi Product Moment}

Sudijono (2011) mengemukakan bahwa. "Product moment correlation atau lengkapnya Product of the moment correlation - adalah salah satu teknik untuk mencari korelasi antara dua variabel yang kerap kali digunakan". Berdasarkan hal tersebut maka rumus ini digunakan untuk mengetahui efektivitas penggunaan metode inkuiri serta mengklasifikasikan data yang terkumpul kemudian dianalisis dengan menggunakan korelasi product moment antara variabel $(x)$ dan variabel (y) sebagai berikut.

$$
r=\frac{\mathrm{N} \sum \mathrm{XY}-\left(\sum \mathrm{X}\right)(\Sigma \mathrm{Y})}{\sqrt{\left\{\mathrm{N} \sum \mathrm{X}^{2}-(\Sigma \mathrm{X})^{2}\right\}\left\{\mathrm{N} \sum \mathrm{Y}^{2}-(\Sigma \mathrm{Y})^{2}\right\}}}
$$

(Sudijono; 2011)

Keterangan :

$r=$ nilai korelasi (antara variabel $x$ dan $y$ )

$\mathrm{N}=$ jumlah siswa yang diteliti

$\mathrm{X}=$ nilai pretes

$\mathrm{Y}=$ nilai postes

$\Sigma \mathrm{X}=$ jumlah nilai pretes

$\Sigma X=$ jumlah nilai postes

$\sum X Y=$ jumlah hasil kali nilai pretes dan postes

$\Sigma X^{2}=$ jumlah kuadrat nilai pretest

$\Sigma Y^{2}=$ jumlah kuadrat nilai postes

Setelah diperoleh nilai $r$, untuk mendapatkan taraf yang signifikan dan tingkat kepercayaan kemudian nilai $r$ hitung dikonsultasikan ke tabel $r$ product moment. Sedangkan untuk mengetahui besarnya interpretasi nilai korelasi penulis menggunakan tabel sebagai berikut.

Tabel 2

Interpretasi Koefisien Korelasi

\begin{tabular}{cc}
\hline Interval Koefisien & Tingkat Hubungan \\
\hline $0,00-0,199$ & Sangat rendah \\
$0,20-0,399$ & Rendah \\
$0,40-0,599$ & Sedang \\
$0,60-0,799$ & Kuat \\
$0,80-1,000$ & Sangat kuat \\
\hline
\end{tabular}

(Sugiyono, 2012)

\section{Pembahasan}

\section{Pengumpulan Data}

Penulis pada tahap ini mengumpulkan data yang sesuai dengan kebutuhan penelitian adalah menjawab pertanyaan penelitian yang telah dirumuskan dalam rumusan masalah dan pembahasan. Penulis mengumpulkan data dengan melakukan pembelajaran di kelas VIII B MTs Daarul Uluum PUI Majalengka mulai dari proses uji coba pembelajaran sebelum penggunaan metode inkuiri (pretes) sampai dengan uji coba setelah pembelajaran menggunakan metode inkuiri (postes) untuk mendapatkan data hasil penelitian. Data hasil pretes dan postes ini selanjutnya akan diolah untuk mendapatkan data mengenai pembelajaran menulis kalimat poster dengan menggunakan metode inkuiri. Adapun data yang diperoleh adalah sebagai berikut.

Data mengenai kemampuan siswa dalam menulis kalimat poster sebelum proses pembelajaran. Data ini diperoleh dari hasil pretes, yaitu tes yang dilaksanakan sebelum pembelajaran dengan menggunakan metode inkuiri. Berdasarkan hasil pretes dapat penulis jelaskan bahwa nilai tes 
awal hasil pembelajaran membaca puisi sebelum menggunakan metode inkuiri di kelas VIII MTs Daarul Uluum PUI Majalengka Tahun Ajar 2013/2014 diperoleh data sebagai berikut.

Jumlah siswa seluruhnya 35 orang. Jumlah peserta tes 35 orang Jumlah total perolehan nilai tes yaitu 2355 . Rata-rata nilai tes yaitu 67,29 . Nilai tertinggi yaitu 85 . Nilai terendah yaitu 50 . Jumlah nilai aspek keefektifan kalimat yaitu 665. Jumlah nilai aspek bentuk tulisan yaitu 610 . Jumlah nilai aspek penggunaan ejaan dan bahasa yaitu 775 . Jumlah nilai aspek gambar pendukung poster yaitu 300. Nilai rata-rata aspek keefektifan kalimat yaitu 19,00. Nilai rata-rata aspek bentuk tulisan yaitu 17,43 . Nilai rata-rata aspek penggunaan ejaan dan bahasa yaitu 22,14 . Nilai rata-rata aspek gambar pendukung poster yaitu 8,57 .

Selanjutnya diperoleh data mengenai kemampuan siswa dalam menulis kalimat poster setelah pembelajaran. Data ini diperoleh dari hasil postes, yaitu tes yang dilaksanakan setelah pembelajaran dengan menggunakan metode inkuiri. Berdasarkan hasil postes dapat penulis jelaskan bahwa nilai tes akhir hasil pembelajaran menulis kalimat poster setelah menggunakan metode inkuiri di kelas VIII B MTs Daarul Uluum PUI Majalengka Tahun Ajar 2013/2014 diperoleh data sebagai berikut.

Jumlah siswa seluruhnya 35 orang. Jumlah peserta tes 35 orang. Jumlah total perolehan nilai tes yaitu 2960. Rata-rata nilai tes yaitu 84,57 . Nilai tertinggi yaitu 95 . Nilai terendah yaitu 80 . Jumlah nilai aspek keefektifan kalimat yaitu 750 . Jumlah nilai aspek bentuk tulisan yaitu 770 . Jumlah nilai aspek penggunaan ejaan dan bahasa yaitu 800. Jumlah nilai aspek gambar pendukung poster yaitu 640. Nilai rata-rata aspek keefektifan kalimat yaitu 21,43 . Nilai rata-rata aspek bentuk tulisan yaitu 22,00 . Nilai rata-rata aspek penggunaan ejaan dan bahasa yaitu 22,86 . Nilai rata-rata aspek gambar pendukung poster yaitu 18,29.

Pengolahan dan Analisis Data

Sebelum data hasil penelitian dibahas, terlebih dahulu data tersebut diklasifikasikan untuk memperoleh kejelasan dan perbandingan antara hasil pretes dan postes. Data nilai hasil pretes dan postes selanjutnya diolah dengan perhitungan statistik dengan langkah-langkah sebagai berikut.

Langkah pertama dalam pengolahan data nilai hasil pretes yang digunakan untuk mengukur kemampuan siswa dalam menulis kalimat poster sebelum pembelajaran dengan menggunakan metode inkuiri, penulis menggunakan teknik prosentase dengan menggunakan rumus sebagai berikut.

$$
\begin{aligned}
& \mathrm{P}=\frac{x}{\mathrm{~N}} \mathrm{x} 100 \% \\
& \mathrm{P}=\frac{2355}{35} \times 100 \% \\
& \mathrm{P}=67,29 \%
\end{aligned}
$$

Kemampuan siswa dalam menulis kalimat poster sebelum pembelajaran dengan menggunakan metode inkuiri mencapai $67,29 \%$. Nilai tersebut masih di bawah nilai Kriteria Ketuntasan Minimal (KKM) yaitu 80 atau $80 \%$. Artinya, kemampuan menulis kalimat poster siswa kelas VIII MTs Daarul Uluum PUI Majalengka Tahun Ajar 2013/2014 sebelum pembelajaran menulis kalimat poster dengan menggunakan metode inkuiri tergolong rendah.

Selanjutnya data nilai postes yang digunakan untuk mengukur kemampuan siswa dalam menulis kalimat poster setelah pembelajaran dengan menggunakan metode inkuiri. Dalam hal ini penulis menggunakan teknik prosentase dengan rumus sebagai berikut.

$$
\begin{aligned}
& \mathrm{P}=\frac{\mathrm{x}}{\mathrm{N}} \mathrm{x} 100 \% \\
& \mathrm{P}=\frac{2960}{35} \times 100 \% \\
& \mathrm{P}=84,57 \% \\
& \text { Kemampuan siswa dalam menulis kalimat poster setelah mengikuti pembelajaran dengan }
\end{aligned}
$$




\section{JGI: JURNAL GURU INDONESIA}

2021, 1(1), hlm. $20-26$

https://jurnal.ppjb-sip.org/index.php/igi/index

E-ISSN: XXXX-XXXX | DOI: $\mathrm{xxxxx-xxxxx}$

menggunakan metode inkuiri mencapai $84,57 \%$. Nilai tersebut di atas Kriteria Ketuntasan Minimal (KKM). Artinya, kemampuan menulis kalimat poster siswa kelas VIII MTs Daarul Uluum PUI Majalengka Tahun Ajar 2013/2014 setelah mengikuti pembelajaran menulis kalimat poster dengan menggunakan metode inkuiri ada peningkatan.

Berdasarkan perhitungan dengan menggunakan korelasi product moment diperoleh $r=0,464$. Jadi, keefektifan penggunaan metode inkuiri dalam pembelajaran menulis kalimat poster pada siswa kelas VIII MTs Daarul Uluum PUI Majalengka tahun ajar 2013/2014 adalah $r=0,464$ termasuk kategori sedang.

\section{Simpulan}

Penulis menarik kesimpulan tentang hal-hal yang diperoleh dari hasil penelitian pembelajaran menulis kalimat poster dengan menggunakan metode inkuiri dapat meningkatkan kemampuan siswa. Hal tersebut dapat dapat diketahui dari meningkatnya kemampuan siswa sebesar $17,58 \%$ dan memperoleh korelasi sebesar 0,464 artinya efektif dapat meningkatkan kemampuan siswa dengan tingkat korelasi sedang.

\section{Daftar pustaka}

Djamarah, Syaiful Bahri dan Aswan Zain. (2006). Strategi Belajar Mengajar. Jakarta: PT Rineka Cipta. Gulo,W. (2008). Strategi Belajar Mengajar. Jakarta: PT Grasindo.

Hani Subakti. (2018). Pengembangan Bahan Ajar Menulis Slogan dan Poster Dengan Pendekatan Proses Siswa Kelas VIII SMP Syaichona Cholil Samarinda. Jurnal Pendas Mahakam, Vol 3 (2), 8597.

Nurgiantoro, Burhan. (2010). PenilaianPembelajaran Bahasa BerbasisKompetensi. Yogyakarta: BPFE Yogyakarta.

Sanjaya, Wina. (2011). Strategi Pembelajaran Berorientasi Standar Proses Pendidikan. Jakarta: Kencana Persada Media.

Rianto. (2018). Efektivitas Penggunaan Metode Sugesti-Imajinasi Melalui Media Audio-Visual dalam Pembelajaran Menulis Cerpen Di SMA Kelas X. Jurnal Pendidikan, 1(1), 64-85.

Sudjana, Nana dan Ahmad Rivai. 2011. Media Pengajaran. Bandung: Sinar Baru Algensindo.

Sudijono (2011). Pengantar Statistik Pendidikan. Jakarta: PT Raja Grafindo Persada.

Sugihastuti. (2000). Bahasa Laporan Penelitian. Yogyakarta: Pustaka Pelajar.

Sugiyono. (2012). Metode Penelitian Pendidikan (Pendekatan Kuantitatif, Kualitatif, dan $R \& D$ ). Bandung: Alfabeta.

Surakhmad, Winarno. (2004). Pengantar Penelitian Ilmiah. Bandung: Tarsito.

Tarigan, Henry Guntur. (2008). Menulis Suatu Keterampilan Berbahasa. Bandung: Angkasa. 